\title{
Through the Valley of the Shadow of Death - Surviving the Dreaded Ebola Disease
}

\author{
Adaora Chinenye Okoli-Igonoh ${ }^{a}$ \\ ${ }^{a}$ MD, First Consultants Medical Centre, Lagos, Nigeria
}

On the night of Sunday July 20th, 2014, Patrick Sawyer was wheeled into the Emergency Room at First Consultants Medical Centre, Obalende, Lagos, with complaints of fever and body weakness. The doctor on call admitted him as a case of malaria and took a full history. Knowing that Mr. Sawyer had recently arrived from Liberia, the doctor asked if he had been in contact with an Ebola patient in the last couple of weeks, and Mr. Sawyer denied any such contact. He also denied attending any recent funeral ceremony. Blood samples were taken for full blood count, malaria parasites, liver function test, and other baseline investigations. He was admitted into a private room and started on antimalarial drugs and analgesics. That night, the full blood count result came back as normal and not indicative of infection.

The following day, however, his condition worsened. He barely ate any of his meals. His liver function test result showed his liver enzymes were markedly elevated. We then took samples for HIV and hepatitis screening. At about 5:00 p.m., he requested to see a doctor. I was the doctor on call that night, so I went in to see him. He was lying in bed with his intravenous (I.V.) fluid bag removed from its metal stand and placed beside him. He complained that he had stooled about five times that evening, and he wanted to use the bathroom again. I picked up the I.V. bag from his bed and hung it back on the stand. I told him I would inform a nurse to come and disconnect the I.V. so he could conveniently go to the bathroom. I walked out of his room and went straight to the nurses' station where I told the nurse on duty to disconnect his I.V. I then informed my Consultant, Dr. Ameyo Adadevoh about the patient's condition, and she asked that he be placed on some medications.

The following day, the results for HIV and hepatitis screening came out negative. As we were preparing for the early morning ward rounds, I was approached by an ECOWAS official who informed me that Patrick Sawyer had to catch an 11 o'clock flight to Calabar for a retreat that morning. He wanted to know if it would be possible to be discharged. I told him it wasn't, as he was acutely ill. Dr. Adadevoh also told him the patient could certainly not leave the hospital in his condition. She then instructed me to write very boldly on his chart that on no account should Patrick Sawyer be allowed out of the hospital premises without the permission of Dr. Ohiaeri, our Chief Medical Consultant. All nurses and doctors were duly informed.

During our early morning ward round with Dr. Adadevoh, we concluded this was not malaria, and the patient needed to be screened for Ebola Viral Disease. She immediately started calling laboratories to find out where the test could be carried out. She was eventually referred to Professor Omilabu of the LUTH Virology Reference Lab in Idi-Araba whom she called immediately. Prof. Omilabu told her to send blood and urine samples to LUTH straight away. She tried to reach the Lagos State Commissioner for Health but was unable to contact him at the time. She also put calls across to officials of the Federal Ministry of Health and National Centre for Disease Control. 
Dr. Adadevoh, at this time, was in a pensive mood. Patrick Sawyer was now a suspected case of Ebola, perhaps the first in the country. He was quarantined, and strict barrier nursing was applied with all the precautionary measures we could muster. Dr. Adadevoh went online, downloaded information on Ebola, and printed copies which were distributed to the nurses, doctors, and ward maids. Blood and urine samples were sent to LUTH that morning. Protective gear, gloves, shoe covers, and facemasks were provided for the staff. A wooden barricade was placed at the entrance of the door to keep visitors and unauthorized personnel away from the patient. Despite the medications prescribed earlier, the vomiting and diarrhea persisted. The fever escalated from $38^{\circ} \mathrm{C}$ to $40^{\circ} \mathrm{C}$.

On the morning of Wednesday 23rd July, the tests carried out in LUTH showed a signal for Ebola. Samples were then sent to Dakar, Senegal for a confirmatory test. Dr. Adadevoh went for several meetings with the Lagos State Ministry of Health. Thereafter, officials from Lagos State came to inspect the hospital and the protective measures we had put in place.

The following day, Thursday 24th July, I was again on call. At about 10:00 p.m., Mr. Sawyer requested to see me. I went into the newly created dressing room, donned my protective gear, and went in to see him. He had not been cooperating with the nurses and had refused any additional treatment. He sounded confused and said he received a call from Liberia asking for a detailed medical report to be sent to them. He also said he had to travel back to Liberia on a 5:00 a.m. flight the following morning, and he didn't want to miss his flight. I told him that I would inform Dr. Adadevoh. As I was leaving the room, I met Dr. Adadevoh dressed in her protective gear along with a nurse and another doctor. They went into his room to have a discussion with him and, as I heard later, to reset his I.V. line which he had deliberately removed after my visit to his room.

At 6:30 a.m., Friday 25th July, I got a call from the nurse that Patrick Sawyer was completely unresponsive. Again, I put on the protective gear and headed to his room. I found him slumped in the bathroom. I examined him and observed that there was no respiratory movement. I felt for his pulse; it was absent. We had lost him. I certified Patrick Sawyer's death. I informed Dr. Adadevoh immediately, and she instructed that no one was to be allowed to go into his room for any reason at all. Later that day, officials from the Word Health Organization (WHO) came and took his body away. The test in Dakar later came out positive for the Zaire strain of the Ebola virus. We now had the first official case of Ebola virus disease in Nigeria.

It was a sobering day. We all began to go over all that happened in the last few days, wondering just how much physical contact we had individually made with Patrick Sawyer. Every patient on admission was discharged that day and decontamination began in the hospital. We were now managing a crisis situation. The next day, Saturday 26th July, all staff of First Consultants attended a meeting with Prof. Nasidi of the National Centre for Disease Control, Prof Omilabu of LUTH Virology Reference Lab, and some officials of WHO. They congratulated us on the actions we had taken and enlightened us further about the Ebola Virus Disease. They said we were going to be grouped into high risk and low risk categories based on our individual level of exposure to Patrick Sawyer, the "index" case. Each person would receive a temperature chart and a thermometer to record temperatures in the morning and night for the next 21 days. We were all officially under surveillance. We were asked to report to them at the first sign of a fever for further blood tests to be done. We were reassured that we would all be given adequate care. The anxiety in the air was palpable.

The frenetic pace of life in Lagos, coupled with the demanding nature of my job as a doctor, means that I occasionally need a change of environment. As such, one week before Patrick Sawyer died, I had gone to my parents' home for a retreat. I was still staying with them when I re- 
ceived my temperature chart and thermometer on Tuesday29th of July. I could not contain my anxiety. People were talking Ebola everywhere - on television, online . . . everywhere. I soon started experiencing joint and muscle aches and a sore throat, which I quickly attributed to stress and anxiety. I decided to take malaria tablets. I also started taking antibiotics for the sore throat. The first couple of temperature readings were normal. Every day I would attempt to recall the period Patrick Sawyer was on admission - just how much direct and indirect contact did I have with him? I reassured myself that my contact with him was quite minimal. I completed the anti-malarials, but the aches and pains persisted. I had loss of appetite and felt very tired.

On Friday 1st of August, my temperature read a high $38.7 C$. As I type this, I recall the anxiety I felt that morning. I could not believe what I saw on the thermometer. I ran to my mother's room and told her. I did not go to work that day. I cautiously started using a separate set of utensils and cups from the ones my family members were using. On Saturday 2nd of August, the fever worsened. It was now at $39^{\circ} \mathrm{C}$ and would not be reduced by taking paracetamol. This was now my second day of fever. I couldn't eat. The sore throat was getting worse. That was when I called the helpline and an ambulance was sent with W.H.O. doctors who came and took a sample of my blood. Later that day, I started stooling and vomiting. I stayed away from my family. I started washing my plates and spoons myself. My parents, meanwhile, were convinced that I could not have Ebola.

The following day, Sunday 3rd of August, I got a call from one of the doctors who came to take my sample the day before. He told me that the sample they had taken was not confirmatory, and they needed another sample. He did not sound very coherent, and I became worried. They came with the ambulance that afternoon and told me that I had to go with them to Yaba. I was confused. Couldn't the second sample be taken in the ambulance like the previous one? He said a better- qualified person at the Yaba centre would take the sample. I asked if they would bring me back. He said "yes." Even with the symptoms, I did not believe I had Ebola. After all, my contact with Sawyer was minimal. I only touched his I.V. fluid bag just that once without gloves. The only time I actually touched him was when I checked his pulse and confirmed him dead, and I wore double gloves and felt adequately protected.

I told my parents I had to go with the officials to Yaba, and I would be back that evening. I wore a white top and a pair of jeans, and I put my iPad and phones in my bag. A man opened the ambulance door for me and moved away from me rather swiftly. Strange behavior, I thought. They were friendly with me the day before, but that day, not so- no pleasantries, no smiles. I looked up and saw my mother watching through her bedroom window. We soon got to Yaba. I really had no clue where I was. I knew it was a hospital. I was left alone in the back of the ambulance for over four hours. My mind was in a whirl. I didn't know what to think. I was offered food to eat, but I could barely eat the rice.

The ambulance door opened and a Caucasian gentleman approached me but kept a little distance. He said to me, "I have to inform you that your blood tested positive for Ebola. I am sorry." I had no reaction. I think I must have been in shock. He then told me to open my mouth, and he looked at my tongue. He said it was the typical Ebola tongue. I took out my mirror from my bag and took a look, and I was shocked at what I saw. My whole tongue had a white coating, looked furry, and had a long, deep ridge right in the middle. I then started to look at my whole body, searching for Ebola rashes and other signs as we had been recently instructed. I called my mother immediately and said, "Mummy, they said I have Ebola, but don't worry, I will survive it. Please, go and lock my room now; don't let anyone inside and don't touch anything." She was silent. I cut the line. 
I was taken to the female ward. I was shocked at the environment. It looked like an abandoned building. I suspected it had not been in use for quite a while. As I walked in, I immediately recognized one of the ward maids from our hospital. She always had a smile for me but not this time. She was ill, and she looked it. She had been stooling a lot too. I soon settled into my corner and looked around the room. It smelled of faeces and vomit. It also had a characteristic Ebola smell to which I became accustomed. Dinner was served - rice and stew. The pepper stung my mouth and tongue. I dropped the spoon. No dinner that night.

Dr. David, the Caucasian man who had met me at the ambulance on my arrival, came in wearing his full protective 'hazmat' suit and goggles. It was fascinating seeing one live. I had only seen them online. He brought bottles of water and oral rehydration solution (ORS), which he dropped by my bedside. He told me that 90 percent of the treatment depended on me. He said I had to drink at least 4.5 litres of ORS daily to replace fluids lost in stooling and vomiting. I told him I had stooled three times earlier and taken Imodium tablets to stop the stooling. He said it was not advisable, as the virus would replicate the more inside of me. It was better, he said, to let it out. He said good night and left. My parents called. My uncle called. My husband called, crying. He could not believe the news. My parents had informed him, as I didn't even know how to break the news to him.

As I lay on my bed in that isolation ward, strangely, I did not fear for my life. I was confident that I would leave that ward someday. There was an inner sense of calm. I did not for a second think I would be consumed by the disease. That evening, the symptoms fully kicked in. I was stooling almost every two hours. The toilets did not flush so I had to fetch water in a bucket from the bathroom each time I used the toilet. I then placed another bucket beneath my bed for the vomiting. On occasion, I would run to the toilet with a bottle of ORS, so that as I was stooling, I was drinking.

The next day, Monday 4th of August, I began to notice red rashes on my skin, particularly on my arms. I had developed sores all over my mouth. My head was pounding so badly. The sore throat was so severe I could not eat. I could only drink the ORS. I took paracetamol for the pain. The ward maid across from me wasn't doing so well. She had stopped speaking. I couldn't even brush my teeth; the sores in my mouth were so bad. This was a battle for my life, but I was determined I would not die.

Every morning, I began the day with reading and meditating on Psalm 91. The sanitary condition in the ward left much to be desired. The whole Ebola thing had caught everyone by surprise. The Lagos State Ministry of Health was doing its best to contain the situation, but competent hands were few. The sheets were not changed for days. The floor was stained with greenish vomitus and excrement. Dr. David would come in once or twice a day and help clean up the ward after chatting with us. He was the only doctor who attended to us. There was no one else at that time. The matrons would leave our food outside the door; we had to go get the food ourselves. They hardly entered in the initial days. Everyone was being careful. This was all so new. I could understand. Was this not how we ourselves had contracted the disease? Mosquitoes were our roommates until they brought us mosquito nets.

Later that evening, Dr. David brought another lady into the ward. I recognized her immediately as Justina Ejelonu, a nurse who had started working at First Consultants on the 21st of July, a day after Patrick Saywer was admitted. She was on duty on the day Patrick reported that he was stooling. While she was attending to him that night, he had yanked off his drip, letting his blood flow almost like a tap onto her hands. Justina was pregnant and was brought into our ward bleeding from a suspected miscarriage. She had been told she was there only on observation. The news that she had contracted Ebola was broken to her the 
following day after results of her blood test came out positive. Justina was devastated and wept profusely — she had contracted Ebola on her first day at work.

My husband started visiting but was not allowed to come close to me. He could only see me from a window at a distance. He visited so many times. It was he who brought me a change of clothes and toiletries and other things I needed because I had not even packed a bag. I was grateful I was not with him at home when I fell ill, or he would most certainly have contracted the disease. My retreat at my parents' home turned out to be the instrumentality God used to shield and save him.

I drank the ORS fluid like my life depended on it. Then I got a call from my pastor. He had been informed about my predicament. He called me every single day morning and night and would pray with me over the phone. He later sent me a CD player, CDs of messages on faith and healing, and Holy Communion packs through my husband. My pastor, who also happens to be a medical doctor, encouraged me to monitor how many times I had stooled and vomited each day and how many bottles of ORS I had consumed. We would then discuss the disease and pray together. He asked me to do my research on Ebola since I had my iPad with me and told me that he was also doing his study. He wanted us to use all relevant information on Ebola to our advantage. So I researched and found out all I could about the strange disease that has been in existence for 38 years. My research, my faith, my positive view of life, the extended times of prayer, study, and listening to encouraging messages boosted my belief that I would survive the Ebola scourge.

There are five strains of the virus, and the deadliest of them is the Zaire strain, which was what I had. But, that did not matter. I believed I would overcome even the deadliest of strains. Infected patients who succumb to the disease usually die between 6 to 16 days after the onset of the disease from multiple organ failure and shock caused by dehydration. I was counting the days and keep- ing myself well hydrated. I didn't intend to die in that ward.

My research gave me ammunition. I read that as soon as the virus gets into the body, it begins to replicate really fast. It enters the blood cells, destroys them, and uses those same blood cells to aggressively invade other organs where they further multiply. Ideally, the body's immune system should immediately mount up a response by producing antibodies to fight the virus. If the person is strong enough, and that strength is sustained long enough for the immune system to kill off the viruses, the patient is likely to survive. If the virus replicates faster than the antibodies can handle, however, further damage is done to the organs. Ebola can be likened to a multi-level, multi-organ attack, but I had no intention of letting the deadly virus destroy my system. I drank more ORS. I remember saying to myself repeatedly, "I am a survivor, I am a survivor."

I also found out that a patient with Ebola cannot be re-infected, and they cannot relapse back into the disease as there is some immunity conferred on survivors. My pastor and I would discuss these findings, interpret them as it related to my situation, and pray together. I looked forward to his calls. They were times of encouragement and strengthening. I continued to meditate on the Word of God. It was my daily bread. Shortly after Justina came into the ward, the ward maid, Mrs Ukoh, passed on. The disease had gotten into her central nervous system. We stared at her lifeless body in shock. It was a whole 12 hours before officials of W.H.O. came and took her body away. The ward had become the house of death. The whole area surrounding her bed was disinfected with bleach. Her mattress was taken and burned.

To contain the frequent diarrhea, I had started wearing adult diapers, as running to the toilet was no longer convenient for me. The indignity was quite overwhelming, but I did not have a choice. My faith was being severely tested. The situation was desperate enough to break anyone psychologically. Dr. Ohiaeri also called us day 
and night, enquiring about our health and the progress we were making. He sent provisions, extra drugs, vitamins, Lucozade, towels, and tissue paper; everything we needed to be more comfortable in that dark hole we found ourselves. Some of my male colleagues had also been admitted to the male ward two rooms away, but there was no interaction with them.

We were saddened by the news that Jato, the ECOWAS protocol officer to Patrick Sawyer who had also tested positive, had passed on days after he was admitted. Two more females joined us in the ward: a nurse from our hospital and a patient from another hospital. The mood in the ward was solemn. There were times we would be awakened by the sudden, loud cry from one of the women. It was either from fear, pain mixed with the distress, or just the sheer oppression of our isolation.

I kept encouraging myself. This could not be the end for me. Five days after I was admitted, the vomiting stopped. A day after that, the diarrhea ceased. I was overwhelmed with joy. It happened at a time I thought I could no longer stand the ORS. Drinking that fluid had stretched my endurance greatly.

I knew countless numbers of people were praying for me. Prayer meetings were being held on my behalf. My family was praying day and night. Text messages of prayers flooded my phones from family members and friends. I was encouraged to press on. With the encouragement I was receiving, I began to encourage the others in the ward. We decided to speak life and focus on the positive. I then graduated from drinking only the ORS fluid to eating only bananas, to drinking pap, and then bland foods. Just when I thought I had the victory, I suddenly developed a severe fever. The initial fever had subsided four days after I had been admitted, and then, suddenly, it showed up again. I thought it was the Ebola. I enquired from Dr. David who said fever was sometimes the last thing to go, but he expressed surprise that it had stopped only to come back on again. I was perplexed.
I discussed it with my pastor who said it could be a separate pathology and possibly a symptom of malaria. He promised he would research if indeed this was Ebola or something else. That night as I stared at the dirty ceiling, I felt a strong impression that the new fever I had developed was not as a result of Ebola but malaria. I was relieved. The following morning, Dr. Ohiaeri sent me antimalarial medication which I took for three days. Before the end of the treatment, the fever had disappeared.

I began to think about my mother. She was under surveillance along with my other family members. I was worried. She had touched my sweat. I couldn't get the thought off my mind. I prayed for her. Hours later, on Twitter, I came across a tweet by W.H.O. saying that the sweat of an Ebola patient cannot transmit the virus at the early stage of the infection. The sweat could only transmit it at the late stage. That settled it for me. It calmed the storms that were raging within me concerning my parents. I knew right away it was divine guidance that caused me to see that tweet. I could cope with having Ebola, but I was not prepared to deal with a member of my family contracting it from me.

Soon, volunteer doctors started coming to help Dr. David take care of us. They had learned how to protect themselves. Among the volunteer doctors was Dr. Badmus, my consultant in LUTH during my housemanship days. It was good to see a familiar face among the care-givers. I soon understood the important role these brave volunteers were playing. As they increased in number, so did the number of shifts increase and, subsequently, the number of times the patients could access a doctor in one day. This allowed for more frequent patient monitoring and treatment. It also reduced care-giver fatigue. It was clear that Lagos State was working hard to contain the crisis.

Sadly, Justina succumbed to the disease on the 12th of August. It was a great blow, and my faith was greatly shaken as a result. I commenced daily Bible study with the other two female patients, and we would encourage one another to 
stay positive in our outlook, though in the natural, it was grim and very depressing. My communion sessions with the other women were very special moments for us all.

On my 10th day in the ward, the doctors, having noted that I had stopped vomiting and stooling and was no longer running a fever, decided it was time to take my blood sample to test if the virus had cleared from my system. They took the sample and told me that I shouldn't be worried if it comes out positive as the virus takes a while before it is cleared completely. I prayed that I didn't want any more samples collected from me. I wanted that to be the first and last sample to be tested for the absence of the virus in my system. I called my pastor. He encouraged me, and we prayed again about the test.

On the evening of the day Justina passed on, we were moved to the new isolation centre. We felt like we were leaving hell and going to heaven. We were conveyed to the new place in an ambulance. It was just behind the old building. Time would not permit me to recount the drama involved with the dynamics of our relocation. It was like a script from a science fiction movie. The new building was cleaner and much better than the old building. Towels and nightwear were provided on each bed. The environment was serene.

The following night, Dr. Adadevoh was moved to our isolation ward from her private room where she had previously been receiving treatment. She had also tested positive for Ebola and was now in a coma. She was receiving I.V. fluids and oxygen support and was being monitored closely by the WHO doctors. We all hoped and prayed that she would come out of it. It was so difficult seeing her in that state. I could not bear it. She was my consultant, my boss, my teacher, and my mentor. She was the imperial lady of First Consultants, full of passion, energy, and competence. I imagined she would wake up soon and see that she was surrounded by her First Consultants family, but sadly it was not to be.

I continued listening to my healing messages. They gave me life. I literally played them hours on end. Two days later, on Saturday the 16th of August, the WHO doctors came with some papers. I was informed that the result of my blood test was negative for Ebola virus. If I could somersault, I would have, but my joints were still slightly painful. I was free to go home after being in isolation for exactly 14 days. I was so full of thanks and praise to God. I called my mother to get fresh clothes and slippers and come pick me up. My husband couldn't stop shouting when I called him. He was completely overwhelmed with joy. I was told, however, that I could not leave the ward with anything I brought in with me. I glanced one last time at my cd player, my valuable messages, my research assistant (a.k.a., my iPad), my phones, and other items. I remember saying to myself, "I have life; I can always replace these items."

I went for a chlorine bath, which was necessary to disinfect my skin from my head to my toes. It felt like I was being baptized into a new life as Dr. Carolina, a WHO doctor from Argentina poured the bucket of chlorinated water all over me. I wore a new set of clothes, following the strict instructions that no part of the clothes must touch the floor or the walls. Dr. Carolina looked on, making sure I did as instructed.

I was led out of the bathroom and straight to the lawn to be united with my family, but first I had to cut the red ribbon that served as a barrier. It was a symbolic expression of my freedom. Everyone cheered and clapped. It was a little but very important ceremony for me. I was free from Ebola! I hugged my family as one who had been liberated after many years of incarceration. I was like someone who had fought death face-to-face and had come back to the land of the living.

We had to pass through several stations of disinfection before we reached the car. Bleach and chlorinated water were sprayed on everyone's legs at each station. As we made our way to the car, we walked past the old isolation building. I could hardly recognize it. I could not believe I slept in that building for 10 days. I was free! Free 
of Ebola. Free to live again. Free to interact with humanity again. Free from the sentence of death.

My parents and two brothers were under surveillance for 21 days, and they completed the surveillance successfully. None of them came down with a fever. The house had been disinfected by Lagos State Ministry of Health soon after I was taken to the isolation centre. I thank God for shielding them from the plague.

My recovery after discharge has been gradual but progressive. I thank God for the support of family and friends. I remember my colleagues who we lost in this battle. Dr. Adadevoh my boss, Nurse Justina Ejelonu, and the ward maid, Mrs. Ukoh were heroines who lost their lives in the cause to protect Nigeria. They will never be forgotten.

I commend the dedication of the W.H.O. doctors, Dr. David from Virginia, USA, who tried several times to convince me to specialize in infectious diseases, Dr. Carolina from Argentina who spoke so calmly and encouragingly, and Mr. Mauricio from Italy who always offered me apples and gave us novels to read. I especially thank the volunteer Nigerian doctors, matrons, and cleaners who risked their lives to take care of us. I must also commend the Lagos State government and the state and federal ministries of health for their swift efforts to contain the virus. To all those prayed for me, I cannot thank you enough. And to my First Consultants family, I say a heartfelt thank you for your dedication and for your support throughout this very difficult period.
I still believe in miracles. None of us in the isolation ward was given any experimental drugs or so-called immune boosters. I was full of faith yet pragmatic enough to consume as much ORS as I could, even when I wanted to give up and throw the bottles away. I researched on the disease extensively and read accounts of the survivors. I believed that even if the mortality rate was $99 \%$, I would be part of the $1 \%$ who survived.

Early detection and reporting to hospital is key to patient survival. Please do not hide yourself if you have been in contact with an Ebola patient and have developed the symptoms. Regardless of any grim stories one may have heard about the treatment of patients in the isolation centre, it is still better to be in the isolation ward with specialist care than at home where you and others will be at risk.

I read that Dr. Kent Brantly, the American doctor who contracted Ebola in Liberia and was flown out to the United States for treatment was being criticized for attributing his healing to God when he was given the experimental drug Zmapp. I don't claim to have all the answers to the nagging questions of life. Why do some die and some survive? Why do bad things happen to good people? Where is God in the midst of pain and suffering? Where does science end and God begin? These are issues we may never fully comprehend on this side of eternity. All I know is that I walked through the valley of the shadow of death and came out unscathed.

This account was first published in BellaNaija 15 Sept 2014.

Competing Interests: None declared.

Cite this article as: Okoli-Igonoh AC. From the valley of the shadow of death - Surviving the dreaded Ebola disease. Christian Journal for Global Health (Nov 2014), 1(2):81-88. http://dx.doi.org/10.15566/cjgh.v1i2.44

(C) Okoli-Igonoh AC. This is an open-access article distributed under the terms of the Creative Commons Attribution License, which permits unrestricted use, distribution, and reproduction in any medium, provided the original author and source are properly cited. To view a copy of the license, visit http://creativecommons.org/licenses/by/3.0/

www.cjgh.org

Nov 2014. Christian Journal for Global Health, 1(2):81-88. 